\title{
Renewable Energy and Rural Autonomy: A Case Study with Generalizations
}

\section{Franciszek Woch ${ }^{1 *}$, Józef Hernik², Hans Joachim Linke³, Edward Sankowski", Milena Bęczkowska ${ }^{5}$, Tomasz Noszczyk ${ }^{2}$}

${ }^{1}$ Department of Soil Science, Erosion and Land Protection, Institute of Soil Science and Plant Cultivation, State Research Institute, Czartoryskich 8, 24-100 Puławy, Poland

${ }^{2}$ Department of Land Management and Landscape Architecture, Faculty of Environmental Engineering and Land Surveying, University of Agriculture in Krakow, Balicka 253C, 30-149 Kraków, Poland

${ }^{3}$ Fachgebiet Landmanagement, Institut für Geodäsie, Fachbereich Bau-und Umweltingenieurwissenschaften, Technische Universität Darmstadt, Franziska-Braun-Str. 7, 64287 Darmstadt, Germany

${ }^{4}$ Department of Philosophy, College of Arts and Sciences, University of Oklahoma, Norman, Oklahoma 73019, United States

${ }^{5}$ Jan Kochanowski University in Kielce, Świętokrzyska 15, 25-406 Kielce, Poland

\author{
Received: 12 March 2017
}

Accepted: 26 May 2017

\begin{abstract}
The aim of the study was to evaluate the potential to satisfy some energy needs of a rural municipality using renewable energy sources. The research was conducted in the territory of the Municipality of Nowa Słupia in Świętokrzyskie Voivodeship, Poland. The novel aspect of this study was to assess current and potential production of energy from renewable sources. The study included consideration of sources of energy such as the sun, water, wind, and biogas of plant origin; and distinguishing actual, potential, and overall renewable energy sources in the period from the time of the study to 2025 . The assessment was based on the sum of existing individual sources and also on opportunities revealed in a development trend analysis of these energy sources. Currently, the municipality does not consume energy from renewable energy sources. In view of the potential volume of energy from renewables, the municipality could meet the demands of its residents at $7.6 \%$. The current volume of thermal energy from renewables, it is here estimated that the municipality could meet the demands at the level of $10.3 \%$. In the future, this source could be developed further beyond the present level of $65.8 \%$, which together with energy crop biomass obtained on set-aside land (approximately $70 \%$ of available land) would cover $76.1 \%$ of the requirements of municipality residents. This article also includes a few more general ideas about sustainable development and energy as suggested by the case study.
\end{abstract}

Keywords: renewable energy sources, energy autarky, energy policy, energy autonomy, energy self-sufficiency, Poland

*e-mail: fwoch@iung.pulawy.pl 


\section{Introduction}

Energy, one of the most important resources necessary for life, is interrelated with the economic development of the state [1]. The nature of social and economic development that we observe today owes much to the availability of energy [2]. If energy were not provided, we would have to change the consumer-driven lifestyle we are so used to. Energy is as essential to modern society as are air and water. Efficient energy management should, however, provide energy not only for current generations but also for future ones, and minimise the negative impact on the environment [3]. Population increases in some areas, economic growth, and some technological changes over recent decades have aggravated environmental pollution and caused a reduction in fossil fuel resources [4-5].

Today we are facing an energy crisis brought about by the gradual depletion of traditional sources of energy [6]. As extraction moves to increasingly more difficult geological conditions [7], the costs of fossil fuel extraction (or purchase) will go up in some places [8]. Non-renewable resources used in the past to produce energy such as hard coal, lignite, and oil are becoming more expensive in some geographical areas because their consumption is increasing, while their total available quantities are dwindling (Fig. 1) [9]. Fossil fuels are replenished over (a very long) time, whereas renewable energy sources (RES) like wind and waves are 'replenished over space.' It would, therefore, require a more time-focused strategy to deal sustainably with fossil fuels, and a more spacefocused strategy to deal sustainably with renewables [10]. Additionally, combustion of coal, oil, or gas affects the climate and environment, hence the need to employ alternative sources offered by nature [11-12]

Fig. 1 shows the depletion of fossil fuels, which is one of the factors that have led to increased interest in RES. Also, their availability is limited by standards related to the extraction of raw materials [7]. There are available,

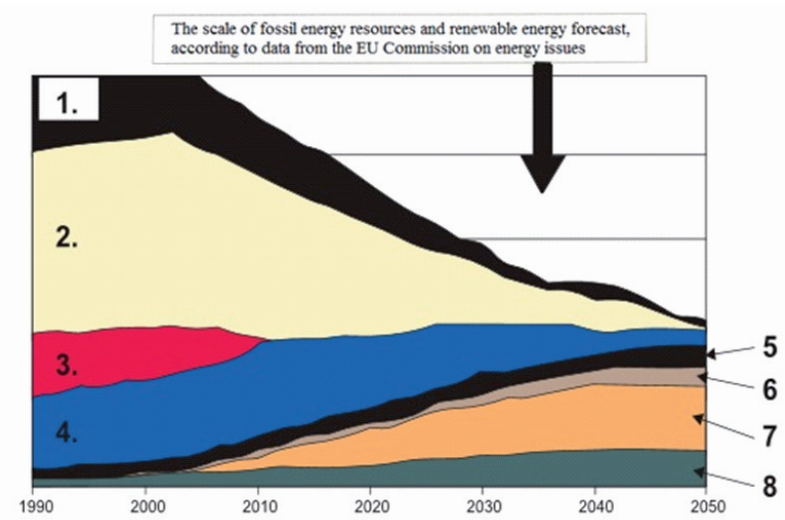

Fig. 1. Conventional energy resource depletion and forecast increase of renewable energy sources in 1990-2050. The basic assumptions of energy consumption across Europe are: 1) coal, 2) oil, 3) uranium, 4) natural gas, 5) water, 6) wind 7) the sun, and 8) biomass. Source: [13]. for example, relatively recent innovative technologies such as horizontal hydraulic fracturing of shale rock for oil and gas extraction, which despite being a significant part of the world energy portfolio, conflicts with onsurface property such as buildings, with industries such as tourism, agriculture, fisheries, public health, and so on. The consumption of fossil fuels and the resulting emissions of carbon dioxide $\left(\mathrm{CO}_{2}\right)$ are among the main causes of global warming and climate change [14]. Another problem, beyond fracking-related issues, is the high pollution associated with the conversion of fossil fuels into heat or electricity [15]. Therefore, some societies have begun to consider using energy from alternative sources such as the sun, wind, earth, waves, ocean currents, and biomass [16]. The big advantage of these alternative energy sources is that they cannot be depleted because they are replenished on a regular basis by natural processes. RES are simultaneously widely believed to be cheaper, safer, and more promising [17-20].

Researchers and academics have been recently more and more interested in the concept of energy autarky, also referred to as 'energy autonomy' or 'energy self-sufficiency' [21-25]. According to Abegg [15, p. 367], many European regions have declared themselves 'energy regions.' They pursue the ambitious goal of becoming independent of the external supply of fossil fuels and energy [21]. This vision of energy self-reliance is overwhelming. Not only does it involve the use of RES, but also proposes effective, economical, and innovative uses of non-renewable energy. The pillars of this idea are spatial planning and transport efficiencies [15].

According to Müller et al. [22], energy autarky means a situation in which a region does not import significant volumes of energy resources, but uses its own resources instead to meet its energy needs. The authors define autarky not only as related to self-reliance of supply, but also in terms of sources of energy, a decentralised structure of power system, and increased energy efficiency of both supply and demand [22]. The notion of autarky has been defined by Scheer [26] as well. He considers energy autonomy to be focused on decentralised models of renewable energy systems with particular focus on autonomous initiatives of individuals, local communities, or investors [26]. The definition suggested by Saxony's energy agency (saena.de) stressed that energy selfsufficiency is not feasible without energy savings and increased energy efficiency [15].

Advocates of autarky believe that local production of energy could be beneficial on numerous levels such as new and local jobs [27], reduced transport distance for energy resources [22], strengthened regional identity [15], protection from price increases in the future [22], and boosts in tourism [28]. We should keep in mind that some oppose the notion of energy autarky. They argue that it may result in high costs of changing the energy system, possible protests and social reluctance [24], and indirect change of land use with its impact on food production (which is hard to measure and may, in fact, be unpredictable) [29]. 
Over the last dozen or so years, rural areas in Poland have gone through dynamic changes related to changing functions [30], human impact on the environment [31], EU membership [32], etc. Apart from the primary function of the agricultural industry, which is to produce food, rural areas are expected to maintain elements of the cultural landscape as well [33]. At the same time, according to Woch et al. [23], rural areas, with their conditions favourable to RES, are becoming an important component of the renewable energy scheme.

In light of the above, the aim of this article is to assess the ability to satisfy energy needs of a rural area based on a case study of RES in the Municipality of Nowa Stupia. We do not, however, take into account changing demand. This question is saved for future studies.

\section{Materials and Methods}

\section{Characteristics of the Study Area}

The Municipality of Nowa Słupia is located in the eastern part of Kielecki District (powiat - a secondtier administrative unit in Poland) in the central part of Świętokrzyskie Voivodeship, Poland. The total area of the 20 villages comprising the municipality is 8,594 ha. At the end of 2015, the study area had a population of 9,962: 4,887 men and 5,075 women. The average population density in the municipality is rather high at 116 people per $1 \mathrm{~km}^{2}$ [34].

The basic economic function of the examined area is agriculture. In terms of land use structure, agricultural land occupies $63.8 \%$ of the municipality, and forests $34.3 \%$. The forests in the municipality provide great conditions for recreation and improve water regulation [34]. The area is dominated by small farms with a surface area of 5 hectares, which occupy $66.3 \%$ of the total surface area of the agricultural land. Those with a surface area of over 15 hectares constitute only $2.7 \%$ of the land surface area. According to the Municipal Office of Nowa Słupia, up to 982 hectares of agricultural land were set aside.

The Municipality of Nowa Słupia is valuable in terms of its environmental assets. Within its boundaries, there are a National Ecological Network ECONET - Poland, ecological network NATURA 2000, and Świętokrzyski National Park, which together with its buffer zone was included in the Polish part of the European ecological network NATURA 2000 [35]. The municipality has four distinct nature reserves.

\section{Research Methodology}

This article contains data and information collected during fieldwork relevant to the present case study. Field research consisted of making an inventory of the existing and potential RES and gathering data from the Municipal Office of Nowa Słupia and the Marshall Office of the Świętokrzyskie Voivodeship in Kielce. An analysis of the
RES in the municipality and their long-term development until 2025 has been conducted.

In order to determine the potential of solar conditions in this study, the sunshine hours as per the map of sunshine duration in Poland together with solar irradiance were considered [36]. The information on the number of installed solar collectors in the study area was obtained from the National Renewable Energy Service; whereas the prospective growth of this energy source has been estimated on the basis of a relevant trend and its recognition among institutions and individuals in industry-related circles [37].

Information on the use of hydropower in the study area was obtained from the Environmental Protection Programme for the Municipality of Nowa Słupia [38].

The effective wind energy in $\mathrm{kWh} \cdot \mathrm{m}^{-2} \cdot$ year $^{-1}$ was obtained from maps created for Poland [39]. The value is derived from an analysis of the potential and limitations specified in respect to this energy source.

An assessment of the conditions for the use of geothermal energy was based on a data study concerning the potential of using geothermal energy in Świętokrzyskie Voivodeship [40].

On the basis of data obtained from the Łagów Forest Division (Forest Management Plan), the amount of energy generated from wood harvested from local forests in the form of wood waste and firewood has been estimated. In order to estimate the wood resources from the forests within the boundaries of the municipality administered by the Łagów Forest Division, we used the following formula [41-42]:

$$
Z_{d l}=A \cdot I \cdot\left(F_{w} \cdot F_{e}\right)\left[m^{3} \cdot \text { year }^{-1}\right]
$$

...where $Z_{\mathrm{dl}}$ is wood from forests for energy purposes $\left(\mathrm{m}^{3} \cdot\right.$ year $\left.^{-1}\right), \mathrm{A}$ is the surface area of forests $(\mathrm{ha}), \mathrm{I}$ is annual increment of volume $\left(\mathrm{m}^{3} \cdot \mathrm{ha}^{-1} \cdot\right.$ year $\left.^{-1}\right), \mathrm{F}_{\mathrm{w}}$ is percentage of wood harvested for industry purposes $(\%)$, and $\mathrm{F}_{\mathrm{e}}$ is percentage of wood harvested for energy purposes $(\%)$.

The index of wood harvested for industry purposes is assumed to be $55 \%$, with the rate of harvesting for energy of $25 \%$ [43-44]. The theoretical yield of wood from the forests was estimated by assuming density of $0.65 \mathrm{t} \cdot \mathrm{m}^{-3}$ [44].

Data on the set-aside land surface area was obtained from the Municipal Office of Nowa Słupia. Based on the results of fieldwork and soil maps for agricultural purposes, the possibility of using these lands for energy crops has been evaluated [for soil data and climate conditions, see 45-49]. Due to the low profitability of energy crops (with the exception of parcels immediately adjacent to the forest) the study excluded parcels smaller than 0.3 hectares.

Literature data has been analysed, taking into account the economic elements [50-51], including information collected in the field, mainly presented on maps. On the basis of the collected material, the characteristics of selected types of alternative energy sources and the positive 
and negative effects of their use have been described. This data allowed us to make proposals for new possibilities of producing heat or electricity from renewable energy sources in the Municipality of Nowa Stupia. The proposals were based mainly on an analysis of the physical and geographical conditions of the municipality.

In the final part, the existing RES in the studied area and their potential were identified and compared with the energy needs of the municipality, taking into account the criteria and data provided by the Polish Ministry of Economy.

\section{Results and Discussion}

The following types of energy have been included in the analysis of the production of renewable energy in the Municipality of Nowa Słupia: hydropower, solar, wind, geothermal, and biomass energy.

\section{Hydropower}

Studies show that no energy generated using surface water is currently consumed in the Municipality of Nowa Stupia. Only small hydroelectric power plants can be built on rivers in the municipality. There are also some old mills that could be rebuilt. The potential number of hydropower plants depends on the surface area of water and the energy potential of surface water in the area [52-53]. Small-scale water retention plans for the municipality involve the construction of three reservoirs in the villages: Jeleniów, Milanowska Wólka, and Baszowice by 2018 , which would then reach $2,400 \mathrm{~km}^{2}$ of surface area. The construction of these reservoirs, with total capacity of $100 \mathrm{~kW}$, will facilitate production of $688 \mathrm{MWh}(2,477 \mathrm{GJ})$ of electricity a year.

In the future, it will be possible to use these reservoirs for energy production by building small hydropower plants that will produce the electricity needed to operate the reservoir and to meet some needs of local residents.

\section{Solar Power}

Nowa Słupia has 1,550 potential hours of sunshine per annum. The solar irradiance throughout the year is within the range of 1,000 to $1,100 \mathrm{kWh} \cdot \mathrm{m}^{-2}$. The conditions for solar energy are good.

Nevertheless, only a small amount of solar energy is generated and consumed in the municipality, with only 87 solar energy systems in the study area [37]. Examples include solar thermal collectors used for heating water in a swimming pool in Rudki village. Moreover, there are three solar thermal collectors installed in Milanowska Wólka used for heating tap water in a 2201 tank and heating a $110 \mathrm{~m}^{2}$ flat. In Nowa Słupia, there are solar thermal collectors consisting of 48 evacuated tubes (four panels on two sides of the roof) used for heating tap water in a 3001 tank and for heating a $140 \mathrm{~m}^{2}$ flat [37]. The total surface area of solar thermal collectors in the municipality is $206 \mathrm{~m}^{2}$, and their power is $444,000 \mathrm{kWh}$.

Solar thermal collectors (and recently also photovoltaic panels) receive great public support; they are considered to be safe and environmentally friendly sources of heat and electrical power [54].

Nowa Słupia has great conditions for solar collectors. It is a rural municipality and has large unused roof spaces on farm, residential, livestock, and public buildings where solar systems could be set up easily. In light of the above, a double generation of thermal energy from this source can be expected. Energy from the Sun can be a major source of power in the study area, especially in the summer, when it provides a large amount of energy that can be used for heating water or drying agricultural products.

\section{Wind Energy}

There are no wind resource maps for the region. In order to estimate energy resources, a map for the whole country was used. The northeastern part of the region where winds can reach speeds of 4.5 to $5.0 \mathrm{~m} \cdot \mathrm{s}^{-1}$ has favourable conditions, while the southwestern part is less favourable [55]: the winds reach 4.0 to $4.5 \mathrm{~m} \cdot \mathrm{s}^{-1}$.

Poland has good wind conditions [56-57], which has spurred increasingly dynamic development of the wind power industry as wind turbines become more widespread [58]. Barriers to the development of the wind power sector in Poland include, first of all, a long and complicated investment process, attitudes of local authorities, local government, and environmental organisations [57].

According to the data of the Energy Regulatory Office [59], the total power of wind turbines in Poland was 1,600 MW at the end of 2011 [57]. At the end of 2016, there were 1,188 wind turbines of total power of 5,782 MW operating in Poland [59]. Despite the existing barriers and limitations, the pace of development of the wind energy sector in Poland has accelerated in recent years [60].

Świętokrzyskie Voivodeship is located in two of the eight wind-energy zones, which justifies estimating wind energy in the range of 750 to 1,000 and 1,000 to $1,025 \mathrm{kWh} \cdot \mathrm{m}^{-2} \cdot$ year $^{-1}$ [39]. By contrast, Nowa Stupia is situated in the preferred zone. For example, in the neighbouring Municipality of Raków, which has similar wind conditions, there is a large area, approximately 300 hectares, designated for a wind farm in the zoning plan [23].

The other important factor affecting the potential of wind energy is land cover and its topography [23, 58, 61]. Wind turbines can be used for producing electricity for small farms. There are no wind turbines in the study area as of the date this article was released for publishing. However, the capacity of this source of energy could be estimated at approximately $1,000 \mathrm{~kW}$, i.e., 7,886 GJ per year for 2025 . However, due to areas of protected environment (Świętokrzyski National Park and its buffer zone, nature reserves, the landscape park and its buffer zone, monuments of inanimate nature, and 
NATURA 2000 under the Nature Conservation Act), the possibilities of installing wind turbine systems are limited [60].

\section{Geothermal Energy}

The Study of Geothermal Energy Opportunities in the Świętokrzyskie Voivodeship [62] shows that there are no favourable conditions for geothermal energy production in the Municipality of Nowa Słupia. As water temperatures are above $20^{\circ} \mathrm{C}$ in the study area, there are some prospects of harnessing geothermal energy for heating purposes. This, however, requires the installation of high-circulation devices, mainly heat pumps, as well as a coproduction with conventional heating units for re-heating tap water at low outdoor temperatures [63]. Such water can be used directly for gardening, recreational, medical, and cultural purposes. Currently, there are no geothermal systems in the study area.

Heat pumps can be used to harvest geothermal energy in the Municipality of Nowa Słupia. Up to 3 MWh (11 GJ) could be achieved for one such device. Assuming the installation of five systems, this could give the potential of $15 \mathrm{MWh}$ (55 GJ).

Poland is one of the richest European countries in terms of low-temperature geothermal resources [64]. The best conditions for harvesting geothermal energy were found across the Polish Lowlands and in the Podhale region in southern Poland [65]. Potentially good conditions have been found in the Sudety in southwestern Poland. However geothermal energy plays a marginal role within the structure of renewable energy resources in terms of the whole country [66].

\section{Biomass Energy}

There are 2,422 hectares of forests in the analysed municipality, which comprises $34.3 \%$ of its total area. Assuming an annual gross increment of wood (with bark and slash) at the Łagów Forest Division of $7.27 \mathrm{~m}^{3} \cdot \mathrm{ha}^{-1}$ [67] and given the criteria contained in Formula (1), the possible total harvested wood volume in the Municipality of Nowa Stupia is $2,430.0 \mathrm{~m}^{3}$. Assuming an average density of $750 \mathrm{~kg}$ per $1 \mathrm{~m}^{3}$ and calorific value of wood (bark) of $10 \mathrm{MJ}$ per $1 \mathrm{~kg}$, the total potential of heat energy is $18,224 \mathrm{GJ}$ a year.

Taking into account the potential increase in the forest cover of the municipality of $1 \%$ (approx. $85 \mathrm{ha}$ ), the logging of trees and orchards should generate an increase in the amount of firewood by approximately $1,400 \mathrm{~m}^{3}$ to approximately $3,830 \mathrm{~m}^{3}$, which potentially generates about 28,725 GJ of heat energy. Cointegration studies' results for developing and emerging countries show that there is a cointegration between biomass energy consumption and economic growth [68].

Set-aside agricultural land is fairly common in the municipality of Nowa Stupia, as the study area is dominated by poor-quality land with a significant level of fragmentation, which adversely results in a chequered structure interspersed with forested parcels and generally low profitability of the agricultural land [69].

Potentially, fallow land may be used for growing energy crops [70-71]. Taking into account the natural conditions such as soil quality, topography, groundwater level, and nearby forests [72], and in light of abundant literature [73-74], three types of energy crops that can be grown on set-aside land in the studied municipality are proposed: Virginia mallow (Sida hermaphrodita) (200 ha), black locust (Robinia pseudoacacia L) (120 ha), and giant miscanthus (Miscanthus giganteus) (180 ha). This way a total of 500 ha - half of the set-aside land - could be used.

The average size of dry matter of the crop of the individual plants each year is [75]:

Virginia mallow (approx. $13.7 \mathrm{t} \cdot \mathrm{ha}^{-1}$ ): 2,740 t.

Black locust (approx. $7 \mathrm{t} \cdot \mathrm{ha}^{-1}$ ): $840 \mathrm{t}$.

Giant miscanthus (approx. 18.4 t $\cdot \mathrm{ha}^{-1}$ ): 3,312 t.

Summing up these values, the total amount of biomass that could be produced in the municipality of Nowa Słupia is $6,892 \mathrm{t} \cdot$ year $^{-1}$. The average calorific value of energy crop dry biomass is about $16 \mathrm{MJ} \cdot \mathrm{kg}^{-1}$ [76]. The potential energy crops in the study area would generate $110,272 \mathrm{GJ} \cdot$ year $^{-1}$.

It should be noted that there is some controversy about the benefits of using biomass as a source of energy. Some claim, for example, that the use of biomass may contribute to global warming and may have harmful health effects. Nonetheless, it is still the case that the official position of the United States Environmental Protection Agency is that when correctly used, biomass could contribute to environmental benefits as opposed to some other commonly used fuels.

Biofuels are liquid fuels resulting from the processing of animal and vegetable products. Raw materials for the production of liquid fuels may be: canola, maize, sugar beets, or grain [77]. Świętokrzyskie Voivodeship has favourable conditions for the growth of maize and rapeseed [78].

About 400 litres of bioethanol can be produced from about one ton of maize kernels [79]. Part of the area used for grain farming could also be used for the cultivation of maize, which further increases the production capacity of bioethanol. It was assumed that in the Nowa Słupia a change in the production of maize for kernels of a minimum of eight hectares can be initiated, which would give approximately $140 \mathrm{t}$ of maize kernels, and thus 8,000 litres of bioethanol, i.e., 2,660 GJ. Maize has a large energy potential, and from a technical point of view it is easier to use its kernels to produce bioethanol than to produce biogas from fermented green parts of the plant [79].

Biogas is derived from biomass, in particular the processing of animal waste, plants, products of sewage treatment plants, or landfills. The particular importance of biogas is connected with its wide application, as it is used for energy production, direct and indirect heat production, and as fuel [6]. Nowa Słupia does not currently have a landfill where landfill gas could be obtained. The 
Table 1. The volumes of energy from the existing and potential renewable energy sources in the Municipality of Nowa Słupia.

\begin{tabular}{|c|c|c|c|}
\hline \multirow{2}{*}{ Type of RES } & \multicolumn{3}{|c|}{$\begin{array}{l}\text { Volume of energy from renewable sources } \\
\qquad\left(\text { GJ } \cdot \text { year }^{-1}\right)\end{array}$} \\
\hline & Existing & $\begin{array}{l}\text { Potential } \\
(2025)\end{array}$ & Total \\
\hline Solar power & $1,597.00$ & $3,200.00$ & $4,797.00$ \\
\hline Hydropower & - & $2,477.00$ & $2,477.00$ \\
\hline Wind power & - & $7,886,00$ & $7,886.00$ \\
\hline Geothermal energy & - & 55.00 & 55.00 \\
\hline Wood waste & $18,224.00$ & $10,501.00$ & $28,725.00$ \\
\hline Energy crops & - & $110,272.00$ & $110,272.00$ \\
\hline Bioethanol from maize & - & $2,660.00$ & $2,660.00$ \\
\hline Biogas from waste water & - & 33.30 & 33.30 \\
\hline Biogas from small gas plants & - & 0.09 & 0.09 \\
\hline Total & $19,821.00$ & $137,084.39$ & $156,905.39$ \\
\hline
\end{tabular}

municipal waste from the community is disposed of in a landfill in Promnik near Kielce.

Another source of biogas is the sewage treatment plant. Studies show that different substances fed to the digester may generate between $10 \mathrm{dm}^{3}$ to $600 \mathrm{dm}^{3}$ of gas $\cdot \mathrm{kg}^{-1}$ DOM [80].

There are two municipal sewage treatment plants in Nowa Słupia: Rudki and Stara Słupia. They collected about $37.0 \mathrm{Mg}$ of sewage sludge in 2011 [38]. Assuming that $50 \mathrm{dm}^{3}$ of biogas can be generated from $1 \mathrm{~kg}$ of DOM, wastewater that is delivered to the treatment plants in the municipality is a potential source of $1,850 \mathrm{~m}^{3}$ of eco-friendly gas, which yields 9,250 kWh (33.3 GJ) ( $1 \mathrm{~m}^{3}-5 \mathrm{kWh}$ of heat or electricity).

The latest idea that is slowly being introduced into the Polish market is to build domestic biogas plants. The most important factors in Poland impacting the development of agricultural biogas plants are rural structure and the profile of agricultural activities [8182]. The resulting eco-friendly gas can be used in many ways, e.g., $1 \mathrm{~m}^{3}$ of biogas can be used for fuelling a $1 \mathrm{hp}$ engine for two hours, equivalent to approximately 0.7 litres of petrol, and produces $1.25 \mathrm{kWh}$ of electricity. It is, therefore, a valuable product. The construction of domestic biogas plants is a very good response to the demand of cheaper heat for rural households [6]. Four hundred litres $\left(0.4 \mathrm{~m}^{3}\right)$ of biogas can be made within about a month from $1 \mathrm{~kg}$ of dry grass, which gives $4.8 \mathrm{~m}^{3}$ per year. Thus, a single farm can generate $24 \mathrm{kWh}(0.09 \mathrm{GJ})$ of electricity or heat per year from $1 \mathrm{~kg}$ of dry grass a month.

The volumes of the energy acquired from various sources in the area of the study are shown in Table 1. It shows that the energy gained from renewable sources can be increased almost by a factor of 7 by the year 2025 .

\section{Evaluation of the Potential to Meet Energy Needs of the Study Area from RES}

The population of the study area is 9,962. Data from the Central Statistical Office and the Ministry of Economy of 2012 shows that the national annual heat energy consumption for heating a household of three is about $58 \mathrm{GJ}$, while the electricity consumption is about $13.7 \mathrm{GJ} \cdot$ person $^{-1} \cdot$ year $^{-1}$ [83]. The data above shows that in order to meet the energy needs of the residents of Nowa Słupia, the thermal energy from RES should exceed 192,598.7 GJ per year, and electricity, 136,479.4 GJ per year, giving a total of $329,078.1$ GJ of energy per year.

Today, no electricity is produced from RES in Nowa Stupia. Heat energy produced from RES in the municipality is currently $19,821 \mathrm{GJ}$ per year, which covers the needs of about $10.3 \%$ of the residents. With the potential use of the above-mentioned sources an additional 10,363 GJ of electricity could be generated, which would cover a further $7.6 \%$ of the demand for electricity. The amount of additional thermal energy would be 126,721 GJ, i.e., $65.8 \%$, with a total that would provide $146,542.39$ GJ, which would cover $76.1 \%$ of the demand for thermal energy of the residents.

If thermal energy was additionally generated from potential renewables, this could grow more than seven times, satisfying the thermal energy needs of $76.1 \%$ of residents, including approximately $70 \%$ with energy crop biomass from set-aside land. By contrast, the current production of electricity can meet the demand of $7.6 \%$ of the population. Nevertheless, it has been observed that political incentives are necessary in order to increase the use of forest biomass. Addressing social acceptance will be a prerequisite for the success of initiatives or legislation to fulfil this potential [84]. 
The total volume of energy produced from RES could be greater because the energy production capacities of hydropower, solar, geothermal, or domestic biogas systems assumed in the article are relatively low. The limitations arise mainly from the existence of arguably excessive restrictions on the implementation of many projects owing to environmental conditions, mainly because of limits related to NATURA 2000. In a sense this is ironic, but one reason it is interesting is because of different ways of conceptualizing how to organize environmental protection, and there is room for strategic planning conflicts here. In this case, the pursuit of the environmentalist goal of increased renewable energy sources is limited by the environmentalist designation of an area as one with very exceptional natural assets.

\section{Conclusions}

1. Currently, no electricity is generated from RES in the study area of the municipality. The prospective amount of energy gained can meet $7.6 \%$ of the demand.

2. The current volume of production of thermal energy from alternative sources satisfies the demand of residents for this type of energy at the level of $10.3 \%$. In the future, with an expected increase of approx. $65.8 \%$, it would satisfy the needs of $76.1 \%$ of the residents of the municipality, including $70 \%$ with energy crop biomass from set-aside land.

3. The largest volume of energy could be obtained from energy crops and waste left after forest-logging, as well as in solar energy systems. However, a necessary precondition of any large change would clearly be a widespread adoption of perennial energy crops by farmers [85].

4. The study area has 982 hectares of land set aside primarily due to the poor quality of soil as well as adverse environmental conditions. It is, therefore, advisable to use approximately half of the area of the set-aside land for the cultivation of energy crops.

5. In the Municipality of Nowa Słupia, solar energy should be used as the main source of electricity.

6. A further increase in energy from renewable sources is limited by environmental conditions, especially by the NATURA 2000 program.

In order to obtain data for practical applications, the temporal availability and demand for heat and electricity have to be taken into account. Therefore, a seasonal, weekly, and daily time-variation curve of the power supply by renewable energy sources and demand for heat and electricity for the town of Nowa Słupia has to be drafted. Storage systems have to be planned, if necessary. For long-term results, the effects of climate change have to be taken into consideration [86]. Finally, a model of implementation of the operation of such renewable energy sources has to be developed considering financial and organisational aspects such as energy cooperatives. Therefore, local stakeholders must be involved in such an energy transformation process for several reasons.
The process will change the landscape of the area, e.g., by adding windmill parks or large photovoltaic facilities. This should be acceptable to the inhabitants of that area. To use renewable energy makes it necessary that the user of the energy system changes their behavior, e.g., to adapt the consumption of energy to its periods of availability. The population should at least be willing to reduce the demand for energy through energy-saving measures. Only a well-integrated combination of all these different aspects can bring about energy autarky of rural areas.

\section{Acknowledgements}

This Research was financed by the Ministry of Science and Higher Education of the Republic of Poland (project No. DS 3371/KGPiAK/2017).

We thank the anonymous reviewers for their constructive comments, which helped to substantially improve the manuscript.

\section{References}

1. ZEVERTE-RIVZA S., PILVERE I., RIVZA P. Integration of risks and political changes in dynamic modelling of biogas production. 13th International Scientific Conference on Engineering for Rural Development, Jelgava, Latvia 2930.05.2014, 13, 541, 2014.

2. CHODKOWSKA-MISZCZUK J. Small-scale renewable energy systems in the development of distributed generation in Poland. Moravian Geographical Reports, 22 (2), 34, 2014.

3. ABBASPOUR M., KARBASSI A., ASADI M.K., MOHARAMNEJAD N., KHADIVI S., MORADI M.A. Energy Demand Model of the Household Sector and Its Application in Developing Metropolitan Cities (Case Study: Tehran). Polish Journal of Environmental Studies, 22 (2), 319, 2013.

4. SLIZ-SZKLINIARZ B. Assessment of the renewable energy-mix and land use trade-off at a regional level: A case study for the Kujawsko-Pomorskie Voivodship. Land Use Policy, 35, 257, 2013.

5. FRANTAL B. Living on coal: Mined-out identity, community displacement and forming of anti-coal resistance in the Most region, Czech Republic. Resources Policy, 49, 385, 2016.

6. SZYMAŃSKA D., LEWANDOWSKA A. Biogas Power Plants in Poland-Structure, Capacity, and Spatial Distribution. Sustainability, 7 (12), 16801, 2015.

7. IGLINSKI B., BUCZKOWSKI R., CICHOSZ M. Biogas production in Poland-Current state, potential and perspectives. Renewable \& Sustainable Energy Reviews, 50, 686, 2015.

8. HERNIK J., RUTKOWSKA A., NOSZCZYK T. Correlation between selected socioeconomic variables and the number of renewable energy sources in Świętokrzyskie Voivodeship (Poland). 15th International Scientific Conference: Engineering for Rural Development, Jelgava, Latvia 2527.05.2016, 15, 498, 2016.

9. FRANTAL B., NOVAKOVA E. A curse of coal? Exploring unintended regional consequences of coal energy in the Czech Republic. Moravian Geographical Reports, 22 (2), $55,2014$. 
10. VAN DER HORST D. Landscapes of lost energy: counterfactual geographical imaginary for a more sustainable society. Moravian Geographical Reports, 22 (2), 66, 2014.

11. PASKA J., SURMA T. Electricity generation from renewable energy sources in Poland. Renewable Energy, 71, 286, 2014.

12. MCCARTHY P., RASUL M.G., MOAZZEM S. Analysis and comparison of performance and emissions of an internal combustion engine fuelled with petroleum diesel and different bio-diesels. Fuel, 90 (6), 2147, 2011.

13. STĘPNIAK S. Energetyczne i biochemiczne parametry paliwa biogazowego, wytwarzanego z odpadów rolniczych. Przegląd Energetyczny, 48 (4), 28, 2007.

14. IPCC, Climate Change 2013: The Physical Science Basis. Cambridge, United Kingdom and New York, NY, USA, 2013.

15. ABEGG B. Energy self-sufficient regions in the European Alps. Mountain Research and Development, 31 (4), 367, 2011.

16. MURADIN M., FOLTYNOWICZ Z. Potential for Producing Biogas from Agricultural Waste in Rural Plants in Poland. Sustainability, 6 (8), 5065, 2014.

17. SZLAVIK J., CSETE M. Climate and Energy Policy in Hungary. Energies, 5 (2), 494, 2012.

18. LEHMANN P., CREUTZIG F., EHLERS M.-H., FRIEDRICHSEN N., HEUSON C., HIRTH L., PIETZCKER R. Carbon Lock-Out: Advancing Renewable Energy Policy in Europe. Energies, 5 (2), 323, 2012.

19. GAWLIK L., SZURLEJ A., WYRWA A. The impact of the long-term EU target for renewables on the structure of electricity production in Poland. Energy, 92, 172, 2015.

20. KARYTSAS S., THEODOROPOULOU H. Socioeconomic and demographic factors that influence publics' awareness on the different forms of renewable energy sources. Renewable Energy, 71, 480, 2014.

21. BROSIG C., WAFFENSCHMIDT E. Energy Autarky of Households by Sufficiency Measures. Energy Procedia, 99, 194, 2016.

22. MULLER M.O., STAMPFLI A., DOLD U., HAMMER T. Energy autarky: A conceptual framework for sustainable regional development. Energy Policy, 39 (10), 5800, 2011.

23. WOCH F., HERNIK J., WIKLINA U., TOLAK M. Energy Autarky of Rural Municipality Created on the Basis of Renewable Energy Resources. Polish Journal of Environmental Studies, 23 (4), 1441, 2014.

24. SCHMIDT J., SCHONHART M., BIBERACHER M., GUGGENBERGER T., HAUSL S., KALT G., LEDUC S., SCHARDINGER I., SCHMID E. Regional energy autarky: Potentials, costs and consequences for an Austrian region. Energy Policy, 47, 211, 2012

25. ENGELKEN M., ROMER B., DRESCHER M., WELPE I. Transforming the energy system: Why municipalities strive for energy self-sufficiency. Energy Policy, 98, 365, 2016.

26. SCHEER H. Energy Autonomy: The Economic, Social and Technological Case for Renewable Energy. London, UK, Earthscan, 2007.

27. BERNDES G., HANSSON J. Bioenergy expansion in the EU: Cost-effective climate change mitigation, employment creation and reduced dependency on imported fuels. Energy Policy, 35 (12), 5965, 2007.

28. JIRICKA A., SALAK B., EDER R., ARNBERGER A., PROBSTL U. Energetic tourism: exploring the experience quality of renewable energies as a new sustainable tourism market. Sustainable Tourism Iv, 139, 55, 2010.

29. STATTMAN S.L., MOL A.P.J. Social sustainability of Brazilian biodiesel: The role of agricultural cooperatives. Geoforum, 54, 282, 2014.
30. GŁOWACKA A., JANUS J., BOŻEK P. Non-urban area ownership structure. Case study of Southern Poland. Geodesy and Cartography, 65 (2), 219, 2016.

31. CEGIELSKA K.M., SALATA T., GAWROŃSKI K., RÓŻYCKA-CZAS R. Level of spatial differentiation of anthropogenic impact in Małopolska. Journal of Ecological Engineering, 18 (1), 200, 2017.

32. BAŃSKI J., MAZUR M. Classification of rural areas in Poland as an instrument of territorial policy. Land Use Policy, 54, 1, 2016.

33. HERNIK J., CZESAK B., NOSZCZYK T., PAZDAN M. Cultural landscape and land use in the rural areas of Poland. In: Cultural landscapes in the context of socio-economic changes in Poland and China; Hernik J., Chen G.; Gawroński K. Eds., Publishing House of the University of Agriculture in Krakow: Kraków, Poland, pp. 11-21, 2015.

34. Municipality of Nowa Słupia Development Strategy for 2016-2023. Available online: http://www.nowaslupia. bip.jur.pl/dokumenty/strategia_rozwoju_gminy_nowa_ slupia_na_lata_2016_12011016_aktualizacja.pdf (accessed 12.12.2016).

35. BĘCZKOWSKA M. Energy autarky in rural areas as illustrated by the case of the Municipality of Nowa Słupia. Thesis, Jan Kochanowski University, Kielce, 88 pp., 2013.

36. Solar resource maps for Poland. GHI Solar Map (C) 2016 Solargis. Available online: http://solargis.com/products/ maps-and-gis-data/free/download/poland (accessed 18.10.2016).

37. National Renewable Energy Local Government Service. Association of Polish Counties website. Available online: http://www.eo.org.pl/ (accessed 18.10.2016).

38. OKRAJEWSKA R., KURKOWSKI S. Program Ochrony Środowiska dla Gminy Nowa Słupia na lata 2012-2015 w perspektywie do roku 2019. Available online: http:// www.nowaslupia.bip.jur.pl/dokumenty/program_ochrony_ srodowiska 2012.pdf (accessed 14.12.2016).

39. LORENC $\bar{H}$. Structure and wind energy resources in Poland. Research Materials of Meteorology Institute, Warsaw, 1996.

40. PACOCHA A. Perspektywy rozwoju odnawialnych źródeł energii w Świętokrzyskiem. Marshall Office of the Świętokrzyskie Voivodeship, Kielce, 2012.

41. BUCZEK J., KRYŃSKA B. Biomass resources - rules and indicators for creating the balance of biomass. In: Materiaty Szkoleniowe: Innowacje w technologiach roślinnych podstawą kształtowania rolniczej przestrzeni produkcyjnej przez samorząd terytorialny; Uniwersytet Rzeszowski: Rzeszów, Poland, pp. 1-8, 2007 [In Polish].

42. BUCZEK J., KRYŃSKA B., TOBIASZ-SALACH R. The evaluation of woody biomass for energetic purposes in Podkarpackie Voivodeship. In: Innowacje w technologiach roślinnych podstawą kształtowania rolniczej przestrzeni produkcyjnej przez samorząd terytorialny, Uniwersytet Rzeszowski: Rzeszów, Poland, 132, 2008 [In Polish].

43. RATAJCZAK E., SZOSTAK A., BIDZIŃSKA G., HERBEĆ M. Demand for wood biomass for energy purposes in Poland by 2015 . Drewno. Prace Naukowe. Doniesienia. Komunikaty, 55 (187), 51, 2012.

44. The demand for biomass for energy purposes in Poland for the years 2006 to 2014. European Centre for Renewable Energy, Warsaw, 2006.

45. JEZIERSKA-THOLE A., RUDNICKI R., KLUBA M. Development of energy crops cultivation for biomass production in Poland. Renewable \& Sustainable Energy Reviews, 62, 534, 2016. 
46. KUŚ J., MATYKA M. Plants cultivation for energy. Institute of Soil Science and Plant Cultivation - State Research Insitute: Puławy, Poland, 2010.

47. PUDEŁKO R., FABER A. Selection of energy plants adapted to cultivation in selected country regions. In: Modern technologies of acquiring and energy use of biomass; Bocian P., Golec T.; Rakowski J., Eds., Energy Institute: Warsaw, Poland, 50, 2010.

48. CHODKOWSKA-MISZCZUK J., SZYMANSKA D. Update of the review: Cultivation of energy crops in Poland against socio-demographic factors. Renewable \& Sustainable Energy Reviews, 15 (9), 4242, 2011.

49. JANKOWSKI K.J., DUBIS B., BUDZYNSKI W.S., BORAWSKI P., BULKOWSKA K. Energy efficiency of crops grown for biogas production in a large-scale farm in Poland. Energy, 109, 277, 2016.

50. LARSSON S., NILSSON C. A remote sensing methodology to assess the costs of preparing abandoned farmland for energy crop cultivation in northern Sweden. Biomass \& Bioenergy, 28 (1), 1, 2005.

51. KRASUSKA E., ROSENQVIST H. Economics of energy crops in Poland today and in the future. Biomass \& Bioenergy, 38, 23, 2012.

52. YI C.-S., LEE J.-H., SHIM M.-P. Site location analysis for small hydropower using geo-spatial information system. Renewable Energy, 35 (4), 852, 2010.

53. BAYAZIT Y., BAKIŞ R., KOÇ C. An investigation of small scale hydropower plants using the geographic information system. Renewable \& Sustainable Energy Reviews, 67, 289, 2017.

54. IGLINSKI B., CICHOSZ M., KUJAWSKI W., PLASKACZDZIUBA M., BUCZKOWSKI R. Helioenergy in Poland - Current state, surveys and prospects. Renewable \& Sustainable Energy Reviews, 58, 862, 2016.

55. KAZAK J., VAN HOOF J., SZEWRANSKI S. Challenges in the wind turbines location process in Central Europe the use of spatial decision support systems. Renewable \& Sustainable Energy Reviews, 76, 425, 2017.

56. MICHALAK P., ZIMNY J. Wind energy development in the world, Europe and Poland from 1995 to 2009; current status and future perspectives. Renewable \& Sustainable Energy Reviews, 15 (5), 2330, 2011.

57. IGLINSKI B., IGLINSKA A., KOZINSKI G., SKRZATEK M., BUCZKOWSKI R. Wind energy in Poland - History, current state, surveys, Renewable Energy Sources Act, SWOT analysis. Renewable \& Sustainable Energy Reviews, 64, 19, 2016.

58. MALCZYK T. Consistency of the Wind Power Industry, Including the Process of Sustainable Planning and Space Management. Polish Journal of Environmental Studies, 25 (2), 699, 2016

59. An interactive map of renewable energy sources. Available online: http://www.ure.gov.pl/uremapoze/mapa.html (accessed 10.01.2017).

60. BRZEZINSKA-RAWA A., GOZDZIEWICZ-BIECHONSKA J. Recent developments in the wind energy sector in Poland. Renewable \& Sustainable Energy Reviews, 38, 79, 2014.

61. STAID A., GUIKEMA S.D. Statistical analysis of installed wind capacity in the United States. Energy Policy, 60, 378, 2013.

62. Study of Geothermal Energy Utilization Opportunities in Świętokrzyskie Voivodeship. Marshall Office of the Świętokrzyskie Voivodeship, Kielce, 2007.

63. BUJAKOWSKI W., BARBACKI A. Potential for geothermal development in southern Poland. Geothermics,
33 (3), 383, 2004.

64. KEPINSKA B. Current state and prospects of geothermalenergy implementation in Poland. Applied Energy, 74 (1-2), 43, 2003.

65. KEPINSKA B. Current geothermal activities and prospects in Poland - an overview. Geothermics, 32 (4-6), 397, 2003.

66. HUCULAK M., JARCZEWSKI W., DEJ M. Economic aspects of the use of deep geothermal heat in district heating in Poland. Renewable \& Sustainable Energy Reviews, 49, 29, 2015.

67. Forest Management Plan for Łagów Forest Division for 2007-2016. Łagów Forest Division, 2008.

68. BILDIRICI M.E. Economic growth and biomass energy. Biomass \& Bioenergy, 50, 19, 2013.

69. JAROS S., WOCH F. Analysis of reasons of arable lands laid fallow in Świętokrzyskie Voivodeship on the example of Kije Community. Studia i Raporty IUNG-PIB, 24, 25, 2010.

70. GAWROŃSKA G., GAWROŃSKI K. The method of assessment of potential ecological effects of obtaining energy from the straw biomass. Acta Scientiarum PolonorumFormatio Circumiectus, 15 (1), 69, 2016.

71. GAWROŃSKA G., GAWROŃSKI K. Method of assessment of potential ecological effects of obtaining energy from the wood willow biomass in Poland. Acta Scientiarum Polonorum-Formatio Circumiectus, 15 (4), 5, 2016.

72. JADCZYSZYN J., FABERA., ZALIWSKIA. Determination of the areas potentially useful for the cultivation of sallow and virginia mallow for energy in Poland. Studia i Raporty IUNG-PIB, 11, 55, 2008.

73. KOCON A., MATYKA M. Phytoextractive potential of Miscanthus giganteus and Sida hermaphrodita growing under moderate pollution of soil with $\mathrm{Zn}$ and $\mathrm{Pb}$. Journal of Food Agriculture \& Environment, 10 (2), 1253, 2012.

74. MATYKA M., KUS J. Influence of Soil Quality for Yielding and Biometric Features of Miscanthus x Giganteus. Polish Journal of Environmental Studies, 25 (1), 213, 2016.

75. KOŁODZIEJ B., MATYKA M. Renewable energy sources. Agricultural energy resources. PWRiL, Poznań, Poland, 594, 2012 [In Polish].

76. TWORKOWSKI J., STOLARSKI M., SZCZUKOWSKI S. Energy efficiency of willow biomass production in the EkoSalix system. Fragmenta Agronomica, 28 (4), 123, 2011.

77. IGLINSKI B., IGLINSKAA., KUJAWSKI W., BUCZKOWSKI R., CICHOSZ M. Bioenergy in Poland. Renewable \& Sustainable Energy Reviews, 15 (6), 2999, 2011.

78. Agriculture in Świętokrzyskie Voivodeship in the 2013 and 2014. Statistical Office, Kielce, Poland, 2015.

79. NOSZCZYK T., HERNIK J., CHABA D. Potential Production of Bioethanol in the Świętokrzyskie Voivodeship (Poland). 16th International Multidisciplinary Scientific Geoconference (SGEM 2016), Albena, Bulgaria, I, 549, 2016.

80. SADECKA Z., MYSZOGRAJ S. Biogas - an unconventional source of energy in wastewater treatment plants. Ekotechnika, 3-4, 35, 2007 [In Polish].

81. ONISZK-POPLAWSKA A., MATYKA M., RYNSKA E.D. Evaluation of a long-term potential for the development of agricultural biogas plants: A case study for the Lubelskie Province, Poland. Renewable \& Sustainable Energy Reviews, 36, 329, 2014.

82. CHODKOWSKA-MISZCZUK J., SZYMANSKA D. Agricultural biogas plants-A chance for diversification of agriculture in Poland. Renewable \& Sustainable Energy Reviews, 20, 514, 2013.

83. Energy Consumption in Households in 2012. Central Statistical Office, Warsaw, Poland, 2014. 
84. ROTHEA., MORONIM., NEYLAND M., WILNHAMMER M. Current and potential use of forest biomass for energy in Tasmania. Biomass \& Bioenergy, 80, 162, 2015.

85. WARREN C.R. Scales of disconnection: mismatches shaping the geographies of emerging energy landscapes. Moravian Geographical Reports, 22 (2), 7, 2014.
86. LINKE H.J., HERLITZIUS L., LÜSSE S., PALOMBA L. Development of cultural landscapes in Germany - topical aspects of the region of Starkenburg in South-Hessen. In: Cultural Landscapes - Across Disciplines; Hernik J., Ed., Oficyna Wydawnicza Branta: Kraków-Bydgoszcz, Poland, 173, 2009. 